\title{
Pyramica baudueri (Emery, 1875) - a new ant species (Hymenoptera: Formicidae) for the Romanian fauna
}

\author{
Bálint MARKó
}

Department of Taxonomy and Ecology, Babes-Bolyai University, 400006 Cluj-Napoca, str. Clinicilor nr. 5-7,
Romania, e-mail: mbalint@biolog.ubbcluj.ro

\begin{abstract}
The Romanian myrmecofauna is insufficiently known, mostly cryptic, sub-Mediterranean and parasitic species are lacking from the checklist. In this article a new species for the Romanian fauna is presented: Pyramica baudueri Em., a cryptic and sub-Mediterranean species. Two specimens were found in South-Western Romania, close to the Hungarian border. P. baudueri lives in the soil, and hunts for small arthropods. Besides Pyramica, specimens of Ponera testacea Em. were also found on the same spot; this is the fifth data on the occurrence of this species in Romania. As several dacetine species are known from Southern and Central European countries it can be hypothesized that specific collecting methods would probably increase the number of dacetine species known from Romania. Upon this article the number of known Romanian ant species sums up to 105.
\end{abstract}

Key words: ants, Pyramica baudueri, new species, Romania

\section{INTRODUCTION}

The ant fauna of Central and Eastern Europe is relatively well-known today. The new wave of the European ant taxonomy in the last decades (e.g. Seifert 1992, Radchenko \& Elmes 2003, Schlick-Steiner et al. 2006) resulted not just in the description of new species and elucidation of taxonomical problems, but also in the renewal or creation of checklists and faunistic monographs Europe-wide. In the last decades several such works were published in Central and Eastern European countries (e.g. Atanassov \& Dlussky 1992, Gallé et al. 1998, Karaman 1998, Seifert 2001, Czechowski et al. 2002, Steiner et al. 2002, Bračko 2006, 2007, Petrov 2006, Werner \& Wiezik 2007). The checklist of the Romanian myrmecofauna was also updated just recently (Markó et al. 2006). Upon this study and a recent publication (Markó 2008) the Romanian fauna currently contains 104 species, which is, however, considerably less than the known fauna of other surrounding countries (see Markó et al. 2006 for comparison). Mostly cryptic, sub-Mediterranean and parasitic species are lacking from the list of the Romanian fauna, but there are also other quite common European species which were not yet reported from Romania, illustrating how insufficiently the fauna is known. In this communication we report the finding of a cryptic, sub-Mediterranean species, which, probably due to its lifestyle and the lack of specific collecting methods, was not detected until now in Romania.

\section{MATERIALS AND METHODS}

Two workers of Pyramica baudueri (Emery, 1875) were collected during a myrmecological field-trip close to Sederhat village (Fig. 1, N 46.200452, E 21.160717, ca. 100 $\mathrm{m}$ a.s.1., Arad County, Western Romania) on 20.05.2007. The specimens were found ca. $30 \mathrm{~cm}$ deep in the soil on a ditch near a narrow channel running parallel and close to the E68 
highway, which connects the cities of Szeged (Hungary) and Arad (Romania). The ditch was covered with sparse vegetation, and the soil surface was relatively dry, sun-exposed.

The identification of the species was carried out using Bolton's comprehensive dacetine key (Bolton 2000). Other ant species found at the same location were identified with the use of other keys (Seifert 1996, Csősz \& Seifert 2003). The Pyramica specimens are deposited in the ant collection of the HNHM (Budapest, Hungary), the other species mentioned in this article are mostly (see text) deposited in the author's personal collection (Dept. of Taxonomy and Ecology, Babeş-Bolyai University, Cluj-Napoca, Romania).

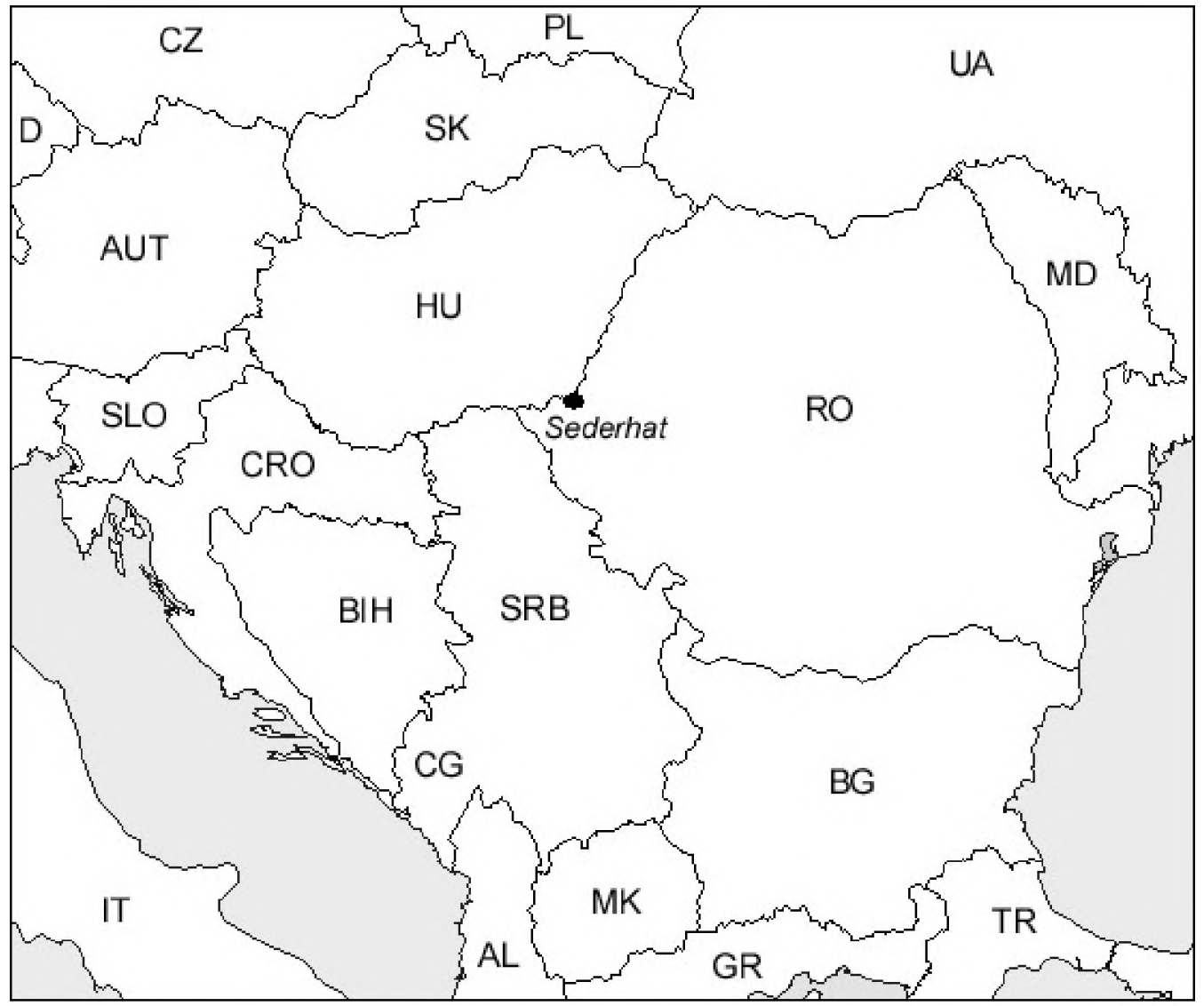

Fig. 1. The location of the collecting site.

\section{NOTES ON THE SPECIES AND FURTHER CONSIDERATIONS}

Pyramica baudueri is a member of the tribe Dacetini within the subfamily Myrmicinae. Dacetini is one of largest tribes, it contains nine genera with 872 species, most of which are tropical or subtropical (Bolton 2000). Within this tribe Pyramica Roger, 1862 is the second largest genus with 324 extant species (Bolton 2000). Only seven dacetine species occur in the West Palaearctic, all members of Pyramica or Strumigenys F. Smith, 1860 genera (Bolton 2000, Radchenko 2007): P. argiola (Emery, 1896), P. baudueri, P. membranifera (Emery, 1869), P. tenuipilis (Emery, 1915), P. tenuissima (Brown, 1953), S. lewisi Cameron, 1886, and 
$S$. rogeri Emery, 1890. Among them $P$. baudueri is one of the most wide-spread and most common dacetine species in Europe. Its known distribution range covers continental France (Bolton 2000, Radchenko 2007), the Channel Islands (Radchenko 2007), Switzerland (Bolton 2000, Braschler 2002), continental Spain (Espadaler 1997, Bolton 2000, Radchenko 2007), the Balearic Islands (Epadaler 1997), continental Italy (Bolton 2000, Radchenko 2007), Corsica (Bolton 2000), Sardinia (Bolton 2000, Radchenko 2007), Sicily (Radchenko 2007), Malta (Radchenko 2007), Tunisia (Bolton 2000), Morocco (Bolton 2000), Greece (Agosti \& Collingwood 1987, Radchenko 2007), Croatia (Bračko 2006), Macedonia F.Y.R. (Radchenko 2007), Montenegro (Petrov 2006), Hungary (Gallé et al. 1998), Turkey (Bolton 2000, Radchenko 2007), and Armenia (Arakelyan 1994).

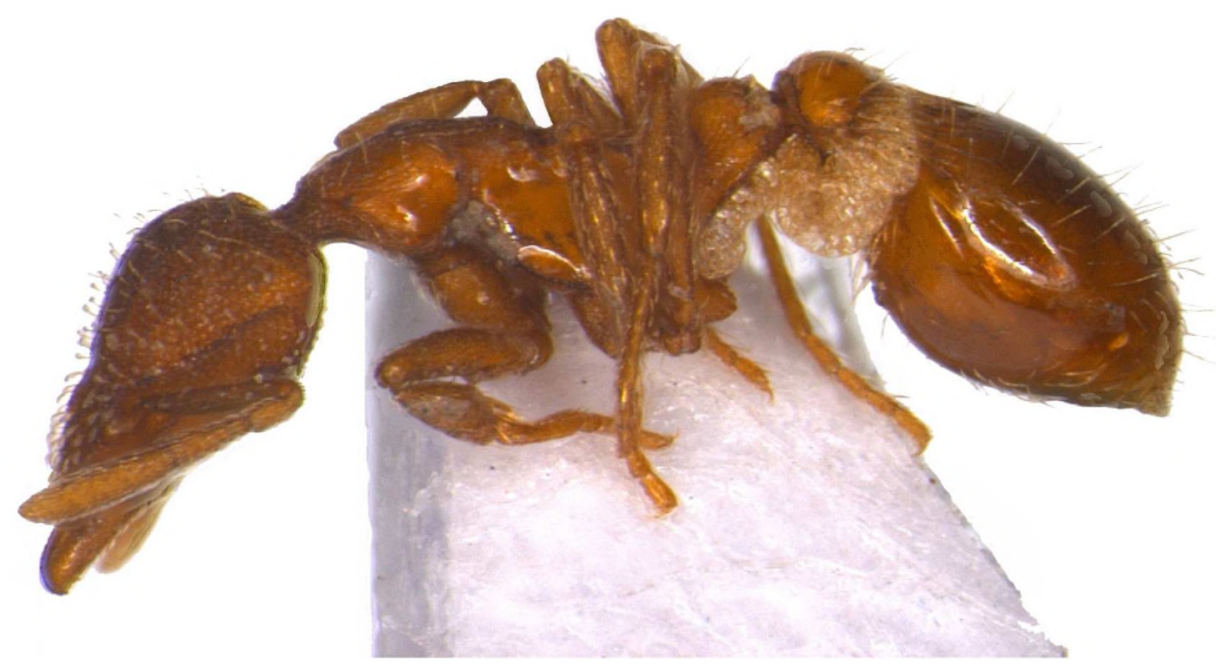

Fig. 2. Lateral view of Pyramica baudueri (photo P. Ślipiński).

Pyramica specimens could be immediately identified in the field as belonging to the tribe Dacetini based on the specific shape of the head. When uncovered from the soil they froze in a strange position: head tilted downward, appendices pulled as close to their body as possible. They stayed motionless even when picked up by the collector. The whole body of this species is slender at first glance, but a closer look reveals its compact feature due to the retractibility of appendices, especially the antennae. The head is pyriform, distinctly elongated anteriorly (Fig. 2 ). The mandibles in full-face view and at full closure are triangular and bear serially dentate masticatory margins. The apical tooth is more or less of the same size than previous teeth. Clypeal dorsum in full-face view is covered entirely by short wide hairs that are broadly spatulate or spoon-shaped and very distinctive. In profile these hairs are directed anteriorly (Fig. 2). The mediodorsally curved ground-pilosity between posterior margin of clypeus and highest point of vertex is also conspicuously spatulate, as are principal curved hairs that project from the leading edge of the scape. The eyes are located ventrolaterally. Cuticle of side of head within scrobe is reticulate-punctate, as well as dorsum of head behind clypeus. The scape is relatively short, in some cases funicular segments 2 and 3 may be fused, and 3 may also be partially or mostly fused to 4 , which could cause identification problems sometimes (Bolton 2000). This is the case with our specimens as well (Fig. 2). Pronotum is lacking a median longitudinal carina. The pleura and the sides of propodeum and disc of postpetiole are smooth 
and shining. Propodeum bears a pair of triangular teeth. There are strongly developed spongiform appendages on the waist, and the ventral curtain on the petiole is deeper than the thickness of the peduncle in profile (Fig. 2).

$P$. baudueri is an exclusively predatory species, which hunts for Collembola or similarsized small arthropods. It lives and forages in the soil, although Braschler (2002) collected two workers with pitfall-traps suggesting that they could also forage on soil surface occasionally. Colonies are usually small and monogynous (Bolton 2000). It is considered to be a subMediterranean species preferring sun-exposed, warm habitats, e.g. calcareous grasslands (Braschler 2002). These specimens were found together with other species, which also prefer such habitat type, like Messor structor (Latreille, 1798), Ponera testacea Emery, 1895 (one specimen is deposited in the collection of the Museum and Institute of Zoology PAS, Warsaw and another in the author's personal collection), Myrmica sabuleti Meinert, 1861, and Solenopsis fugax (Latreille, 1798). More precisely Pyramica baudueri, Ponera testacea and Solenopsis fugax were found on the same spot, at the same soil depth and very close to each other. It is also worth mentioning that there are very few data on Ponera testacea from Romania, thus this finding is also of particular relevance. P. testacea is known only from four localities up to now: Bucharest (Montandon \& Santschi 1910), Deva, Sibiu and Cluj-Napoca (Csősz and Seifert 2003).

Upon the identification of Pyramica baudueri the number of Romanian ant species reaches 105 (Markó et al. 2006, Markó 2008). Currently just a handful of species with cryptic lifestyle are known in Romania: Cryptopone ochracea (Mayr, 1855), Hypoponera punctatissima (Roger, 1859), Ponera coarctata (Latreille, 1802), Ponera testacea, Proceratium melinum (Roger, 1860) and now Pyramica baudueri. With the exception of Ponera coarctata (e.g. Csôsz 2003, Markó et al. 2006) the data regarding all of these species are very scarce, only few sites are known where they occur. Ponera testacea is known from four localities (see above), whereas Cryptopone ochracea is known only from Bucharest (Montandon and Santschi 1910) and from Băile Herculane (Csősz 2003). There is just one reference regarding the occurrence of Hypoponera punctatissima in Romania, in the surroundings of Bucharest (Paraschivescu 1974), and also a single reference is available on Proceratium melinum from Comana Vlasca (Montandon and Santschi 1910).

In addition to Pyramica baudueri the occurrence of other European dacetine species is also expected in Romania based on their distribution or their ecology. Species like Pyramica argiola, known from Hungary (Gallé et al. 1998), Croatia (Bračko 2006), continental Spain (Espadaler 1997), Germany, France, Italy, Switzerland, Greece, Azerbaijan, Georgia, and Tunisia (Bolton 2000), or P. tenuipilis, known from continental Spain (Espadaler 1997), Andorra (Espadaler et al. 2006), France, Corsica, Italy, and Greece (Bolton 2000), could occur in Southern Romania. Moreover we cannot rule out the presence of cosmopolitan tramp species like $P$. membranifera, known from Madeira (Espadaler 2008), the Balearic Islands, continental Spain (Gómez and Espadaler 2006), and Italy (Bolton 2000), and Strumigenys rogeri, known from Great Britain (Bolton 2000, Radchenko 2007). They could easily occur in the vicinity of international harbours at the Romanian Black Sea coast. Most probably the number of known dacetine as well as other cryptic species or at least the data regarding their distribution in Romania, would considerably increase with the application of specific collecting methods (Bolton 2000) instead of occasional 'lucky' free hand collecting.

\section{ACKNOWLEDGMENTS}

I would like to express my gratitude to Piotr Ślipiński for the quality photo and to Alexander Radchenko and Wojciech Czechowski (MIZ PAS, Warsaw) for their improving 
suggestions regarding the manuscript. I am also thankful to Beatrix Ferencz, who assisted me during the collection of the species. This work was supported during the preparation of the article by PL-TAF-5279 Synthesys EU FP 6 grant and by ID-552 IDEI PNII grant (Bucharest, Romania)

\section{REFERENCES}

Agosti D. \& Collingwood C. A. 1987. A provisional list of the Balkan ants (Hym., Formicidae) and a key to the worker caste. I. Synonymic list. Mitteilungen der Schweizerischen Entomologischen Gesellschaft / Bulletin de la Société Entomologique Suisse 60 (1-2): 51-62.

ARAKELYAN G. R. 1994. [Fauna of Republic Armenia. Hymenopteran insects. The ants (Formicidae)]. Gitiutiun, Yerevan, Armenia, 153 pp. [in Russian]

ATANASSOV N. \& DlUSSKY G. M. 1992. Hymenoptera, Formicidae. Fauna Bulgarica 22: 1-310.

BOLTON B. 2000. The ant tribe Dacetini. Memoirs of the American Entomological Institute 65: 1-1028.

BRAČKO G. 2006. Review of the ant fauna (Hymenoptera: Formicidae) of Croatia. Acta Entomologica Slovenica $14(2): 131-156$.

BRAČKO G. 2007. Checklist of the ants of Slovenia (Hymenoptera: Formicidae). Natura Sloveniae 9 (1): 15-24.

BRAsCHLER B. 2002. Neue Aspekte zur Verbreitung von Pyramica baudueri (Emery, 1875) (Hymenoptera, Formicidae). Mitteilungen der Entomologische Gesellschaft Basel 52 (4): 139-142.

CZECHOWSKI W., RADCHENKO A. \& CzECHOWSKA W. 2002. The ants (Hymenoptera, Formicidae) of Poland. Museum and Institute of Zoology PAS, Warsaw, $200 \mathrm{pp}$.

Csốsz S. 2003. A key to the Ponerinae species of the Carpathian Basin (Hymenoptera: Formicidae). Annales Historico-Naturales Musei Nationalis Hungarici 95: 147-160.

Csösz S. \& SEIFERT B. 2003. Ponera testacea Emery, 1895 stat $\mathbf{n}$. - a sister species of P. coarctata (Latreille, 1802) (Hymenoptera, Formicidae). Acta Zoologica Academiae Scientiarum Hungaricae 49 (3): 201-214.

ESPADALER X. 1997. Catàleg de les formigues (Hymenoptera: Formicidae) dels països catalans. Sessió Conjunta d'Entomologia ICHN-SCL 9: 23-42.

Espadaler X., Pujade-Villar J. \& Bernadou A. 2006. Contribució al coneixement de la taxonomia i la fenologia de les formigues (Hymenoptera: Formicidae) d'Andorra. Butlletí de la Institució Catalana d'Història Natural 74: 81-90.

Espadaler X. 2008. Hymenoptera: Formicidae. In: Borges P. A. V., Abreu C., Franquinho Aguiar A. M., Carvalho P., Jardim R., MElo I., SERgio C., Serrano A. R. M. \& VIEIRA P. (eds): A list of the terrestrial fungi, flora and fauna of Madeira and Selvagens archipelagos, pp. 269-270. Direcção Regional do Ambiente da Madeira and Universidade dos Açores; Funchal and Angra do Heroísmo.

Gallé L. Csösz S., TARTAlly A. \& KovÁcs É. 1998. A check-list of Hungarian ants (Hymenoptera: Formicidae). Folia Entomologica Hungarica 59: 213-220.

GómEZ K. \& EsPADALER X. 2006. Exotic ants (Hymenoptera: Formicidae) in the Balearic Islands. Myrmecological News 8: 225-233.

KARAMAN M. 1998. Data about investigations on myrmecofauna (Hymenoptera, Formicidae) in Montenegro. Glasnik Republičkog Zavoda za Zaštitu Prirode i Prirodnjačkog Muzeja u Podgorici 26: 55-62.

MARKO B. 2008. Ants (Hymenoptera: Formicidae) of the "Sand dunes of Foieni" protected area and its surroundings (Satu Mare County, Romania), and a new species for the Romanian fauna. Acta Scientiarum Transylvanica Múzemi Füzetek 16 (3):87-100.

Markó B., Sipos B., Csösz S., Kiss K., Boros I. \& Gallé L. 2006. A comprehensive list of the ants of Romania. Myrmecological News 9: 65-76.

MONTANDON A. L. \& SANTSCHI F. 1910. Contributions á la faune entomologique de la Roumanie. Formicides. Bulletin de la Société Roumaine des Sciences 19: 648-654.

PARASCHIVECU D. 1974. Die Fauna der Formiciden in dem Gebiet um Bukarest. Travaux du Muséum d'Histoire Naturelle "Grigore Antipa" 15: 297-302.

PETRov I. Z. 2006. Mravi Srbije i Crne Gore. [The ants of Serbia and Montenegro]. SANU [Serbian Academy of Sciences and Arts], Beograd, 136 pp. [in Serbian]

RADCHENKo A. 2007. Fauna Europea: Formicidae. In: NoYES, J. (ed.), Fauna Europaea: Hymenoptera: Apocrita. Fauna Europaea version 1.3; http://www.faunaeur.org, accessed on 10.12.2008.

RADCHENKO A. \& ELMES G. W. 2003. A taxonomic revision of the socially parasitic Myrmica ants (Hymenoptera: Formicidae) of the Palaearctic Region. Annales Zoologici 53: 217-243.

Schlick-Stenner B. C., Stenner F. M., Moder K., Seifert B., Sanetra M., Dyreson E., Stauffer C. \& CHRISTIAN E. 2006. A multidisciplinary approach reveals cryptic diversity in Western Palearctic Tetramorium ants (Hymenoptera: Formicidae). Molecular Phylogenetics and Evolution 40: 259-273.

SEIFERT B. 1992. A taxonomic revision of the Palaearctic members of the ant subgenus Lasius $\mathrm{s}$. str. (Hymenoptera: Formicidae). Abhandlungen und Berichte des Naturkundemuseums Görlitz 66: 1-67. 
SEIFERT B. 1996. Ameisen: beobachten, bestimmen. Naturbuch Verlag, Augsburg, 352 pp.

SeIFERT B. 2001. Formicidae. In: DAthe H., TAEger A. \& BlANK S. (eds): Entomofauna Germanica 4. Verzeichnis der Hautflüger Deutschlands. Entomologische Nachrichten und Berichte, Dresden, Beiheft 7: 125-129.

STEINER F. M., SCHÖDL S. \& SCHLICK-STEINER B. C. 2002. Liste der Ameisen Österreichs (Hymenoptera: Formicidae), Stand Oktober 2002. Beiträge zur Entomofaunistik 3: 17-25.

WERNER P. \& WIEZIK M. 2007. Vespoidea: Formicidae (mravencoviti). In: BOGUSCH P., STRAKA J. \& KMENT P. (eds): Annotated checklist of the Aculeata (Hymenoptera) of the Czech Republic and Slovakia. Acta Entomologica Musei Nationalis Pragae, Suppl. 11: 133-164.

\section{STRESZCZENIE}

\section{[Pyramica baudueri (Emery, 1875) - nowy gatunek mrówki (Hymenoptera: Formicidae) dla fauny Rumunii]}

Myrmekofauna Rumunii jest nie w pełni poznana; wśród wykazanych gatunków brakuje zwlaszcza form o skrytym trybie życia, submedyterraneńskich i spolecznie pasożytniczych. Praca przedstawia Pyramica baudueri Em. - malo znany submedyterraneński gatunek z plemienia Dacetini, o skrytym (podziemnym) trybie życia, nowy dla fauny rumuńskiej. Dwa jego osobniki (robotnice) zostaly znalezione w poludniowo-zachodniej Rumunii, blisko granicy z Wegrami. P. baudueri żyje w glebie, gdzie poluje na drobne stawonogi. Poza nią w tym samym miejscu wykazano również Ponera testacea Em.; jest to piąte znane w Rumunii stanowisko tego gatunku. Z Południowej i Środkowej Europy wykazanych jest wiele gatunków Dacetini i można przypuszczać, że zastosowanie specjalistycznych metod zbierania materiału zwiększy liczbę znanych z Rumunii przedstawicieli tego plemienia. Obecnie, włącznie z $P$. baudueri, liczba gatunków mrówek znanych z Rumunii wynosi 105. 